\title{
Phytochemistry and Pharmacological Activities of Boehmeria Genus: An Update Review
}

\author{
Muhammad Ikhlas Arsul ${ }^{1,2, *}$, Muhamad Insanu' ${ }^{1}$, Irda Fidrianny'
}

\section{Muhammad Ikhlas Arsul ${ }^{1,2, *}$ Muhamad Insanu', Irda Fidrianny ${ }^{1}$}

'Department of Pharmaceutical Biology, School of Pharmacy, Bandung Institute of Technology, INDONESIA.

${ }^{2}$ Department of Pharmacy, Alauddin Islamic State University, INDONESIA.

\section{Correspondence}

\section{Muhammad Ikhlas Arsul}

Department of Pharmaceutical Biology, School of Pharmacy, Bandung Institute of Technology; Department of Pharmacy, Alauddin Islamic State University,

INDONESIA.

E-mail: ikkal87@yahoo.co.id

History

- Submission Date: 04-08-2021;

- Review completed: 16-08-2021.

- Accepted Date: 25-08-2021.

DOI : 10.5530/pj.2021.13.195

Article Available online http://www.phcogj.com/v13/i6

Copyright

(C) 2021 Phcogj.Com. This is an openaccess article distributed under the terms of the Creative Commons Attribution 4.0 International license.

\begin{abstract}
Introduction: Boehmeria is a genus that has the potential to be natural medicine and also has benefit in industry. This genus consists of 82 plants that includes numerous species, subspecies, and varieties. The objective of this review is to provide an overview of chemical and pharmacological characteristics of Boehmeria genus based on research studies. Methods: The reference articles have DOI and were obtained through database from such as Science Direct and PubMed website to ensure their validity and reliable contents. This literature study was made by using minimum 50 literatures from the last 10 years. Results: There are 16 species of Boehmeria genus confirmed to have chemical compounds, and 9 species of which reported to exhibit pharmacological activity in the form of extracts and single compound isolates. Conclusion: Based on this study, it was known that some Boehmeria species contained abundance of Boehmeriasin A, boehmeriasin B, chlorogenic acid, epicatechin, (Z)-9,10,11-trihydroxy-12 octadecenoic acid, catechin, $\beta$-sitosterol, rutin, luteolin-7-glucoside, naringin and hesperidin. Boehmeria genus had various activities such as anticancer, anti-inflammatory, antidiabetic, antihyperlipidemic, antimicrobial, antioxidant, and anti-hepatitis B.

Key words: Boehmeria, Chemical compound, Biological activities, Anticancer, Boehmeriasin.
\end{abstract}

\section{INTRODUCTION}

For thousand years, natural products have been used to cure indigenous peoples all over the world. Nowadays natural products are used as a primary therapeutic by around $85 \%$ of the world's population, ${ }^{1}$ as well as a source for drug discovery, with $25-80 \%$ of all synthetic drugs derived from natural products. ${ }^{2}$ Plant derivatives were $24 \%$ of widely prescribed synthetic drugs, with the remaining $9 \%$ being synthetic products modeled from natural products, $6 \%$ being derived directly from plant organisms, and $5 \%$ being of animal origin. ${ }^{3}$ The prediction of organisms on the world is estimated to be 350,000 - 550,000, with just around $20 \%$ of them being studied for medicinal purposes. ${ }^{4}$

One of plant species that has potential to be natural medicine is Boehmeria genus. There are 459 plant species in Boehmeria genus, with 108 species are distinct by combining species with the same synonym and as many as 82 confirmed species. ${ }^{5}$ Boehmeria virgata and Boehmeria depauperata are the only two species that are widely distributed. The most popular is B. virgata, which can be found in West Africa to the Marquesas and Society Islands, and south to Zimbabwe, Madagascar, and Australia through Sudan, Pakistan, and China. It is divided into two subspecies, one of which occurs almost entirely west of Wallace's line (subsp. macrophylla) and the other of which occurs almost entirely east of Wallace's line (subsp. macrophylla) (subsp. virgata). From India (where it's particularly common in the Himalayas) to Indonesian Papua and Papua New Guinea, B. depauperate can be found all over the world. It is not divided into infraspecific taxa east-west. ${ }^{6}$
One species (a B. virgata-like species) is present only in Indochina and southern China; three others are found in Indonesia, and three more in Indonesia, southern India, and Sri Lanka (together with one variety of $B$. virgata). Seven varieties (along with three species of $B$. virgata) have been reported in the Himalayas and their eastern extension into Indochina and China. There are five species present in the Philippines, two of which are also found in Indonesia and/or Papua New Guinea, and one of which is found in Indonesia, Japan (the Ryukyu Islands), and western China ${ }^{6}$.

The Chinese Boehmeria was classified into 32 species and 11 types based on morphology, and the biological characteristics of these genera were determined by phyllotaxis, inflorescence form, and the existence of staminate flowers and achenes, among other characteristics.?

This article is review article, we tried to systematically study phytochemical compounds and pharmacological activities of Boehmeria genus plants during the last 10 years. We will explore this plant, the essential compounds, and effective mechanisms in this article.

\section{METHODS}

Keywords Boehmeria and Boehmeria activity were searched in databases such as ScienceDirect, Google Scholar, and PubMed to ensure their validity and reliable contents, and the papers had to be written in English. Literatures that were not relevant to phytochemistry and pharmacological activities were excluded. There was minimum 50 literatures from the last 10 years.

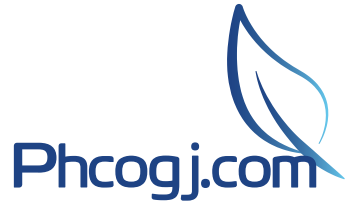

Cite this article: Arsul MI, Insanu M, Fidrianny I. Phytochemistry and Pharmacological Activities of Boehmeria Genus: An Update Review. Pharmacogn J. 2021;13(6): 1533-1541. 


\section{RESULTS AND DISCUSSION}

\section{Boehmeria virgata}

Boehmeria virgata or parang romang was mostly used in folk Makassar medication to cure cancer. ${ }^{8}$ One study identified 10-(6,6-dihydroxyhexyl)-2,3,6-trimethoxy-phenanthrene-9-carboxylic acid amide, or BVI03, an alkaloid derivative of B. virgata (Figure 1). This compound was obtained from $B$. virgata leaves extract and potential as anticancer. Using the 3-[4,5-dimethylthiazol-2-yl]-2,5 diphenyl tetrazolium bromide (MTT) assay process, BVI03 had IC $_{50}$ value of $39.05 \mu \mathrm{g} / \mathrm{ml}$ against Hela cancer cells. Even though this value was categorized as poor, but it demonstrated better results compared to doxorubicin. It is assumed that the cytotoxic effect is due to the rigidity of the phenanthrene structure, so that a strong cytotoxic effect can be given by nitrogenous bases. In addition, phenanthrene compound also contained a C-2 methoxy group, so this group provided compound with cytotoxic activity.

The activity of caspase- 3 was directly assessed against BVI03-induced HeLa cell apoptosis. After BVI03 induction, caspase-3 activity specifically triggered apoptosis. The activity percentage was shown to be $2.66 \%$, indicated it was 6.65 times higher than untreated HeLa cells. During the time of BVI03 administration to Hela cells, p53 protein expression gradually increased within the $\mathrm{p} 53$ apoptotic pathway. The pro-apoptotic protein 553 played an important role in cell death and termination of the cell cycle in the G1 process. ${ }^{10}$

\section{Boehmeria siamensis}

Isolation of Boehmeria siamensis plant obtained boehmeriasin A. After 48 hours of induction, the boehmeriasin A compound had a powerful inhibitory effect on MDA-MB-231 cell formation. MDA-MB-231 cell growth was inhibited by boehmeriasin A, which also induced G1 stage cell capture, cyclin E2, and cyclin D1 expression. In contrast to pretreatment cells, cyclin E2 and cyclin D1 mRNA expression were down-regulated in MDA-MB-231 cells exposed by boehmeriasin A for 8 and 12 hours. These findings promoted boehmeriasin A-induced growth inhibition and phase G1 cessation and also exposed that the effect of boehmeriasin A may be linked to lower expression of these two cyclines, mainly to cyclin E2, that had 50\% reduction in drug use at $12 \mathrm{~h}^{11}$

The antiproliferative activity of enantiomer boehmeriasin A against three lines of human lymphoblastic leukemia (CEM), human cervical carcinoma (HeLa), and mouse lymphocytic leukemia (L1210) cells, as well as two endothelial cells (human microvascular endothelial cells (HMEC-1) and bovine aortic endothelial cells) demonstrated strong cytostatic activity against different tumor cells (BAEC). The previous study stated that (R)-1 showed to be substantially stronger against HeLa $\left(\mathrm{IC}_{50} 66 \mathrm{nM}\right)$ and $\mathrm{L} 1210\left(\mathrm{IC}_{50} 19 \mathrm{nM}\right)$ cells than the (S)enantiomer. Endothelial cell proliferation was also inhibited by the two compounds, with IC50 values of $23 \mathrm{nM}$ in BAEC and 7 and $82 \mathrm{nM}$ in HMEC1 for the (R)- and (S)-enantiomers, respectively. These findings suggested that (R)- and (S)-boehmeriasin A were linked had up to 11 times the inhibitory activity of the (S)-enantiomer against tumor and endothelial cells than the (R)-enantiomer. The racemic mixture has anti-proliferative activity comparable to the enantiomer (R), which was similar in HeLa cells, approximately 2 times more active in CEM and BAEC cells, and 3-4 times less active in L1210 and HMEC-1 cells. ${ }^{12}$

The analogue synthesis of the boehmeriasin A compound was performed in 2 series and then tested for its anticancer activity in both of them (Figure 2). Boehmeriasin A analogs were tested on cellular hepato-carcinoma cells of Huh7 and Mahlavu. Boehmeriasin A analogs 16 and 17 (series 1) have mild cytotoxic values with $\mathrm{IC}_{50}$ values $(19.2$ $\mu \mathrm{M}$ and $9.3 \mu \mathrm{M})$ in Huh7 cells, with $\mathrm{IC}_{50}$ values $(54 \mu \mathrm{M}$ and $13.8 \mu \mathrm{M})$ in Mahlavu 16 and 17 cells. In all types of liver cancer cells (Huh7, Mahlavu, SNU475, FOCUS, Hep3B, HepG2, MCF12A and MCF10A) with mean $\mathrm{IC}_{50}$ values below $0.01 \mu \mathrm{M}$, the analogs 1 and 19 of boehmeriasin $\mathrm{A}$ have demonstrated substantial cytotoxicity. Important growth of both cells was seen in the results of test analogues 1 and 19 (series 2) on hepatocellular carcinoma cells. At $24 \mathrm{~h}(0.01 \mu \mathrm{M}), 48 \mathrm{~h}(0.004 \mu \mathrm{M})$ and $72 \mathrm{~h}(0.01 \mu \mathrm{M})$, drug-resistant Mahlavu cells were more susceptible to analogs 19 compounds. Analog 19 compounds decreased Akt protein phosphorylation, which is involved in the tumorigenesis to liver cancer. Cell death by the activation of cytochrome-C, cleavage of the PARP protein and the blocking of the sub G1 cell cycle characterized cell death. ${ }^{13}$

The analogs compounds of the first series tend to be less active than boehmeriasin A, but the analog compounds of the second series demonstrated remarkable activity for different cancer cell lines compared to boehmeriasin A. ${ }^{13}$

\section{Boehmeria nivea}

Boehmeria nivea, an annual herb plant widely cultivated for its fibers and a type of the Boehmeria family of Urticaceae, is commonly grown in China. In South China, B. nivea has a strong seed germination and can be collected 3 times annually. $B$. nivea leaves are a plentiful byproduct that have been used in folk medicine to treat diarrhea and snake strikes and have been consumed as rice cakes or tea. ${ }^{14}$

There were numerous chemical levels in each part of the $B$. nivea. Bud of $B$. nivea had the largest phenolic value $(4585 \pm 320 \mathrm{mg} \mathrm{GAE} / 100 \mathrm{~g}$

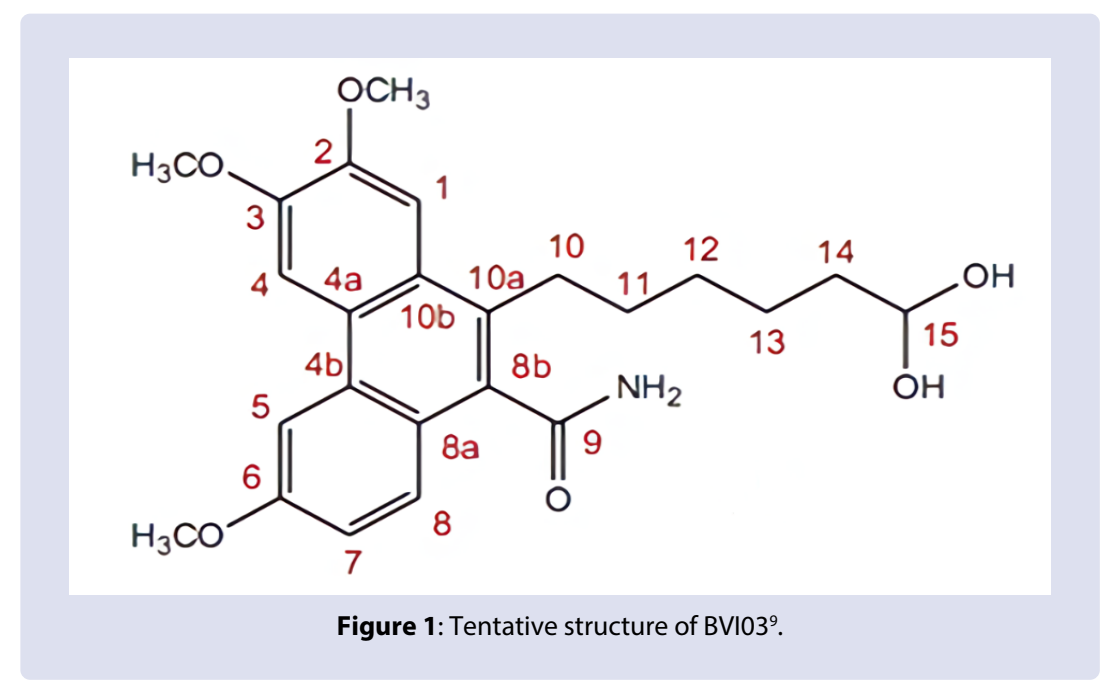




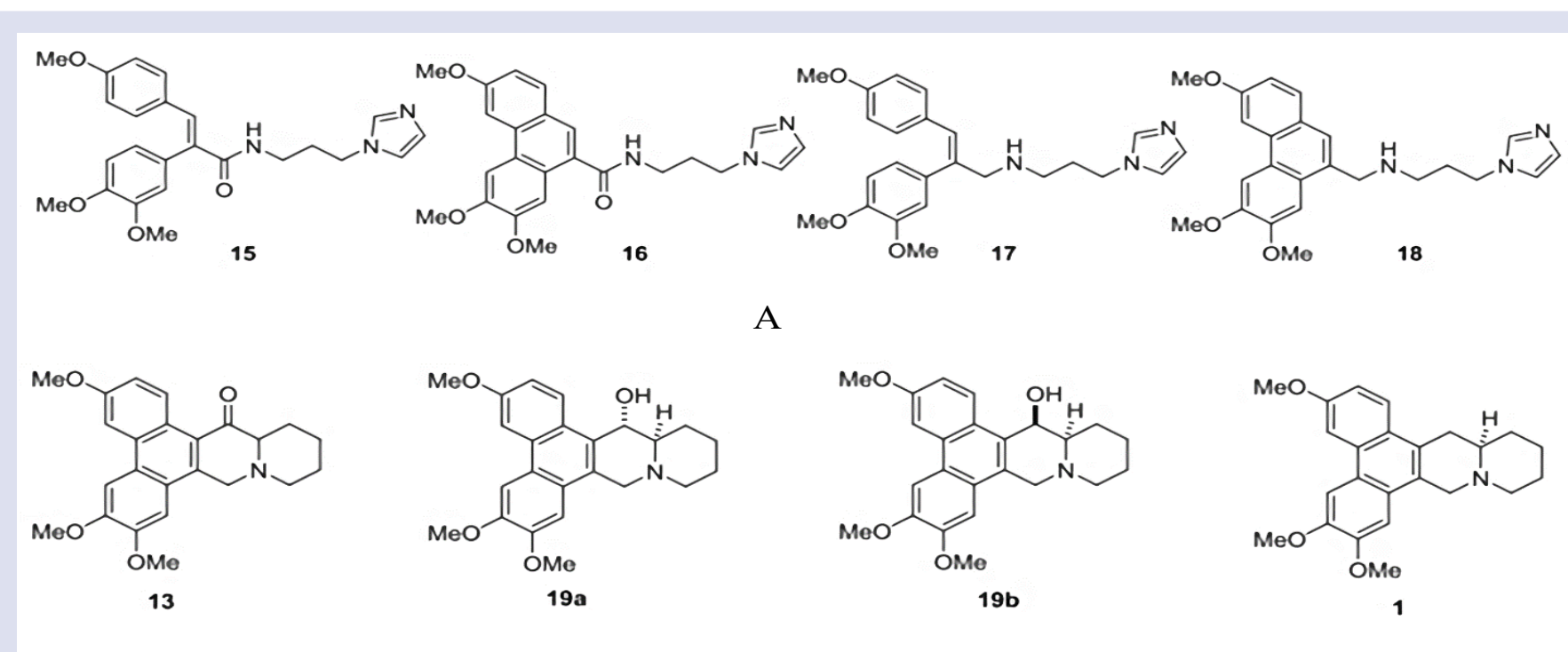

B

Figure 2: New boehmeriasin $A$ analogs. analogs series $1(A)$, analogs series $2(B)^{13}$.

DW) as well as the highest flavonoid amounts $(2755 \pm 184 \mathrm{mg} \mathrm{CE} / 100$ g DW). Benzoic, 4-coumaric, caffeic, and ferulic acid as well as rutin, isoquercetin, kaempferol-3-O-rutinoside, tangeretin, hesperidin, naringin, luteolin-7-glucoside and chlorogenic acid were the dominant phenolic components as phytochemical material. ${ }^{14-18}$ In addition, three unsaturated fatty acids, (Z)-12-keto-7,8,9-trihydroxy-10-hexadecenoic acid, (Z)-7,8,9-trihydroxy-10-hexadecenoic acid, and (Z)-9,10,11trihydroxy-12-octadecenoic acid, as well as a reported unsaturated fatty acid, (E)-8,11,12-trihydroxy acid, were found in the roots of $B$. nivea. ${ }^{19}$

Strong activity in buds where the $\mathrm{EC}_{50}$ value was below $1 \mathrm{mg} \mathrm{DW} / \mathrm{ml}$ was shown by cytotoxic test results using cell line A375, KB cells, and HepG2 cells. B. nivea levels could substantially inhibit the viability of cancer cells and have the potential to have anticancer activity based on test results with an $\mathrm{IC}_{50}$ value of $3.27 \pm 0.050 \mu \mathrm{g} / \mathrm{ml}$ for ethanol extract and $3.79 \pm 0.037 \mu \mathrm{g} / \mathrm{ml}$ for methylene chloride extract on MCF7 cancer cells..$^{20,21}$

B. nivea has antioxidant activity as well. Two approaches were used to assess antioxidant capacity: oxygen radical scavenging capacity (ORAC) and hydrophilic peroxyl radical scavenging capacity (HydroPSC). The total Hydro-PSC content was approximately $2000 \mu \mathrm{mol}$ of vitamin C equiv./100 g FW and Trolox equiv./g FW with ORAC was less than 100 and more than $60 \mu \mathrm{mol}$. The value of $B$. nivea leaves cellular antioxidant activity was $16.27 \mathrm{mmol} \mathrm{QE} / 100 \mathrm{~g}$ FW and the EC50 value was $74.54 \pm 16.84 \mathrm{mg} / \mathrm{ml}^{15}$

Chlorogenic acid from $B$. nivea also displayed antimicrobial effect. Based on size of inhibition zone against $E$. coli, chlorogenic acid has significant antibacterial activity. The inhibition area diameter increased significantly by increasing in chlorogenic acid concentration. ${ }^{16}$ Antifungal activity was demonstrated by $B$. nivea unsaturated fatty acids (Z)-12-keto-7,8,9-trihydroxy-10-hexadecenoicacid, (Z)7,8,9-trihydroxy-10-hexadecenoic acid, (Z)-9,10,11-trihydroxy-12octadecenoic acid, and (E)-8,11,12-trihydroxy-9-octadecenoic acid. While the fungicidal activity of saturated fats was slightly lower than amphotericin $\mathrm{B}$, the findings revealed that the $B$. nivea roots' alleged medicinal effect may be at least partly responsible for the fatty acids. ${ }^{21}$

B. nivea can also be effective in preventing diabetes mellitus (DM). The application of $B$. nivea extract levels at a dose of $0.5 \mathrm{~g} / \mathrm{kg}$ resulted in significant reduction in rapid blood glucose, lipid profile, triglyceride level, uric acid, alanine aminotransferase, aspartate aminotransferase, urine sugar, and urine ketone level in DM rats. At dose of $0.5 \mathrm{~g} /$ $\mathrm{kg}$, treatment with $B$. nivea extract in DM rats for 21 days resulted in a substantial reduction in rapid blood glucose level. The 21-day supplementation of $B$. nivea extract in DM rats showed in a substantial reduction in the amount of plasma total cholesterol and triglyceride. The day after 21 of extract therapy, high-density lipoprotein cholesterol (HDL-C), a beneficial lipoprotein, increased dramatically, while it decreased in the diabetic group. ${ }^{22}$

B. nivea showed that by inhibiting peroxisome proliferator-activated receptor gamma (PPAR- $\gamma$ ) signaling in myotubes, an antidiabetic effect was achieved. In addition, $B$. nivea extract improved the abnormal increase found in high fat diet-fed mice in body mass, liver fat, and blood lipids levels. Glucose resistance was substantially reduced by the administration of extract of $B$. nivea $0.5 \%$ in mice induced by high fat diet. $^{17}$

B. nivea could be used to treat number of allergic disorders caused by inflammation mediated by suppressed mast cells. Therapies using B. nivea have been proved effective in controlling allergic reactions and have been able to suppress development of histamine and $\beta$-hexosaminidase in mast cells. $B$. nivea extract had ability to suppress inflammatory cytokines by downregulating MAPK and NF-B routes suggested that it had therapeutic potential effects on a variety of allergic diseases. $^{22}$

In HepG2.2.15 cells test with Boehmeria leaves extract, $\mathrm{HBs} \mathrm{Ag}$ and $\mathrm{HBe} \mathrm{Ag}$ secretion was decreased without any cytotoxic activity. Moreover, chloroform fraction (CF) and ethyl acetate fraction (EAF) of $B$. nivea were found to be more active than the other fractions on the day 9 after therapy.CF $(100 \mathrm{mg} / \mathrm{L})$ inhibited HBsAg secretion by $94 \pm 1.78 \%\left(\mathrm{IC}_{50}=20.92 \mathrm{mg} / \mathrm{L}\right)$ and $\mathrm{HBeAg}$ secretion by $100.19 \pm 35 \%$ $\left(\mathrm{IC}_{50}=19.67 \mathrm{mg} / \mathrm{L}\right) . \mathrm{EAF}(200 \mathrm{mg} / \mathrm{L})$ also inhibited HBsAg secretion by $89.95 \pm 2.26 \%\left(\mathrm{IC}_{50}=39.90 \mathrm{mg} / \mathrm{L}\right)$ and HBeAg secretion by $98.9 \pm 1.42 \%$ $\left(\mathrm{IC}_{50}=36.45 \mathrm{mg} / \mathrm{l}\right) .{ }^{23}$

Without inducing diarrhea, the $B$. nivea raised the level of mass and water level of rat feces granules, while loperamide reduced the occurrence. The concentration of $B$. nivea also decreased the amounts of remaining of fecal pellets in intestine, which was similar with duration of colon transit, that it was successful in relieving constipation. Treatment using $B$. nivea was substantially protected 
against oxidative stress which caused by intoxication with loperamide. Anti-constipation and antioxidant activity by $B$. nivea was observed may be due to phenolic content and healthy fats. ${ }^{24}$

\section{Boehmeria caudata}

Identification of compounds in Boehmeria caudata yielded seven alkaloid groups, included boehmeriasin $\mathrm{A}$ and $\mathrm{B}$, julandine, 2',4'-dimethoxyacetofenone, (-)-C(15R)- hydroxycryptopleurine, 4-dehydroquinolizidine, 3,4-dimethoxy- $\omega$-(2'-piperidy1) acetophenone, and 3-(4-Hydroxyphenyl)-4-(3-methoxy-4-hydroxyphenyl)-3.25

B. caudata had potential as a chemotherapy agent. The anticancer activity of the B. caudata showed potent activity in the cancer cell types with tumor growth inhibition levels of 0.17-0.66 and $0.11 \mathrm{~g} / \mathrm{ml}$, for NCI-H460 (lung cancer) and K562 (leukemia cancer), respectively. B. caudata also showed potential activity in cancer cell lines U251, MCF7, PC-3, OVCAR-3, and HT29 with TGI value $<6.26 \mu \mathrm{g} / \mathrm{ml}$, except in aqueous extract was inactive for MCF-7. ${ }^{25}$

B. caudata also demonstrated anti-inflammatory activity by oral, intra peritoneal, and topical administration, which inhibited ear mouse edema by $62 \%, 57 \%$, and $41 \%$. Likewise, to the decrease dexamethasone-treated compared to vehicle-treated animals, B. caudata may reduce up to $80 \%$ of ear inflammation regardless of the route and doses of administration. These findings demonstrate that $\mathrm{BC}$ crude extract produces a potential anti-inflammatory effect. ${ }^{25,26}$

\section{Boehmeria macrophylla}

Boehmeria macrophylla is an annual plant which was used in Bangladesh traditional medicine to treat pathologic conditions such as fever, injury, skin infections, and wounds. Boehmeria macrostachya and Boehmeria platyphylla are two species from Urticaceae family that are mostly found in subtropical habitats of the Northern Hemisphere, such as China and Bangladesh. ${ }^{27,28}$

Terpenoids, alkaloids, saponins, steroids, flavonoids, and tannins were presented in B. macrophylla leaves. Furthermore, 8 compounds were isolated from B. macrophylla and named $\beta$-sitosterol, $\beta$-sitosterol glucoside, cinnamic acid, hydroxyl-6-methoxycoumarin (scopoletin), ursolic acid, emodin, sweroside, and 5,7-dihydroxy4' methoxy dihydroflavonol (genistein). ${ }^{27,28}$ Analgesic activity of B. macrophylla extract showed substantial inhibition of writhing impulse $32.91 \%$ and $54.2 \%$ at doses of $0.25 \mathrm{~g} / \mathrm{kg}$ and $0.5 \mathrm{~g} / \mathrm{kg}$, respectively. The analgesic activity obtained, may be caused by polar substances in the leaves extract. At doses of $0.5 \mathrm{~g} / \mathrm{kg}$, B. macrophylla extract significantly decreased the acetic acid-induced twisting response in mice. ${ }^{28}$

The strongest antibacterial effect was observed with dose of $500 \mu \mathrm{g} B$. macrophylla towards some bacterial species (Streptococcus ferus, $V$. cholerae, E. coli and Staphylococcus epidermidis). The B. macrophylla cytotoxic activity against brine shrimp was demonstrated to be effective, with $\mathrm{IC}_{50}$ value $33.16 \mu \mathrm{g} / \mathrm{ml}^{28}$

\section{Anticancer activity of Boehmeria}

Anticancer effects have been demonstrated by many Boehmeria genus. Correlated with cancer mechanism, the processes that occurred in the cell cycle can be related, one of which is the role of p53 and the occurrence of apoptosis. The most critical aspect of cell death is apoptosis, and it is very important to know about the pathogenesis of the disease due to dysfunctional apoptosis to determine the mechanism of apoptosis. ${ }^{29}$ Apoptosis works and is a highly regulated mechanism to kill unnecessary or unwanted cells. There are a number of factors, including DNA damage or uncontrolled proliferation, that will cause the apoptotic pathway to become active. Changes begin to take place inside the cells once apoptosis is marked. One of these improvements is the induction of caspases, which cleave cellular elements like cytoskeletal and nuclear proteins that are needed for normal cellular function. Apoptotic cells shrink and their plasma membranes are modified as a result of caspase activity, signaling a macrophage response. ${ }^{30}$ Uncontrolled growth, angiogenesis, and apoptosis avoidance are all cancer signs that occur in all cancer cells, irrespective of their trigger or category. ${ }^{31}$

One of the key functions of apoptosis is to prevent cancer. ${ }^{32}$ In cancer, it is typically the intrinsic pathway that is blocked, although there are different ways of inhibiting apoptosis. Loss of cell death regulation causes cancer cells to life longer giving them extra opportunities to acquire mutations which could increase tumor invasion, stimulate angiogenesis deregulate cell proliferation, and inhibit differentiation. ${ }^{30}$ Caspases (particle-specific systemic proteases), that are family of cysteine proteins that cleave the other proteins and used for apoptosis. The action of caspase protease is necessary for the success of apoptosis because hundreds of different proteins are cleaved. There are many caspases of initiation (caspase 2, 8, 9, 10) and executor caspase (caspase $3,6,7) \cdot{ }^{33}$

There are many complex processes in the body to defend against the growth of cancer. The mechanism that is often discovered in different cancer types is reduction of pro apoptotic caspase expression. The executor caspase mutation, namely caspase-3 that causes colon cancer, caspase- 6 mutations that cause colorectal cancer and caspase- 7 mutations that cause esophageal cancer, are examples of mutations found in caspase. ${ }^{34}$

Caspase- 3 is a protein that formed through the CASP- 3 gene and a member of the caspase family that activates caspases- 6 and -7; necessary for the formation of apoptotic bodies. Both normal and tumor tissue can be widely expressed in caspase-3. The family of caspases plays an important function in the apoptosis phase. The failure of cells to join the apoptotic phase allows cells that have become neoplastic to continue to divide and acquire additional mutations in their genetic structure, which is connected to changes in the caspase genetic structure and its regulators that underlie the development of cancer. ${ }^{35}$ The loss of expression of caspase- 3 is an important mechanism for the cancer cells persistence and the occurrence of chemoresistance in a variety of cancer cells. The tendency of cancer cells to avoid apoptosis is one of their distinguishing characteristics, which renders cancer cells unresponsive to anti-cancer therapy. ${ }^{36}$

P53-MDM2 is one of the pathways that plays a role in the apoptosis process involving caspase-3. MDM2 acts as an oncogene that has a strong P53 affinity and works to inhibit the ability of the P53 gene's transcription factors and causes P53 to degrade via the ubiquitindependent pathway. Disruption of this process can lead to the growth and chemoresistance of tumors. Targeting the p53 family protein, inhibiting interactions with p53-MDM2, recovering mutated p53 to its ferocious function, removing p53 mutants, produced p53-based antibodies, and gene treatment to recover p53 activity are some of the ways to cause apoptosis targeting p53. ${ }^{37} \mathrm{Via}$ interactions with the p53 transactivation domain (p53TAD) oncoproteins like MDM2 (also known as HDM2 in humans) and MDMX negatively regulate the function of p53. As a result, among of main aims of cancer treatment is to block the $553 \mathrm{TAD}-\mathrm{MDM}$ /MDMX connection using a litle MDM2 antagonist molecule, which sustaining $\mathrm{p} 53$ by blocking its interaction with MDM2 and specifically induces aging in cancer cells. ${ }^{34}$ Expression of $\mathrm{p} 53$ is poor in normal cells and the half-life about $20 \mathrm{~min}$. However, the half-life of $\mathrm{p} 53$ is prolonged by several hours in the case of cellular tension, resulting increasing in concentration of $\mathrm{p} 53$ protein in the cells. The primary function of p53 as a cellular barrier is to understand whether damage is permanent and thus causes apoptosis. ${ }^{38}$ 


\section{Antioxidant activity of Boehmeria}

Boehmeria's antioxidant compounds are thought to work to prevent and neutralize the development of oxidation reactions, both exogenous and endogenous, involving free radicals. Flavonoids are one of the largest phytochemical compounds in Boehmeria, according to the current research. Flavonoids in free form became considerably larger than bounded flavonoid in all selected Boehmeria, which was similar to phenolics. Flavonoids are a category of bioactive plant chemicals identified in infus of herbs, fructus, plants, and herbal medicines. They have also been confirmed to have antioxidant properties and to be capable in inhibiting cellular development. ${ }^{39,40}$ Oxidation reactions involving free radicals, particularly free radicals, can damage the normal cell membranes surrounding them and damage the DNA composition so that a mutation can be induced. Mutations or damage to DNA composition can cause number of degenerative diseases, including cancer, heart failure, eye problems, skin damage, etc. ${ }^{41}$

By preventing ROS generation, directly capturing ROS, or indirectly growing enzymes, flavonoids may have an antioxidant impact. Superoxide and peroxynitrite can directly be captured by flavonoids. Flavonoids increase NO bioavailability by superoxide capture and inhibit the formation of peroxynitrite. Peroxynitrite, which impairs endothelium vacorelaxation and disrupts the endothelium, may also be captured by flavonoids, resulting in greater blood supply in the coronary arteries. Due to the $\mathrm{HO}^{*}$ reaction with nitrogenous DNA bases, flavonoids may also inhibit DNA damage and stimulate the development of enzymatic antioxidants like SOD, catalase and GPX..$^{42}$

\section{Antiallergic activity of Boehmeria}

Phytochemical studies have confirmed that Boehmeria leaves contained polyphenolic compounds such as rutin and hesperidin. It was considered to cure allergic disorder like eczema, rhinitis, and asthma. ${ }^{43-45}$ It was consistent with previous research, that Boehmeria contained abundant components of polyphenols. Based on these known results, it can be suggested that Boehmeria, such as $B$. nivea, may contribute in suppression of IgE-mediated inflammation of mast cells and cold for the potential treatment of allergic diseases. ${ }^{46}$

Chronic immune responses, cellular injury and remodeling, may all result from IgE and mast cell reactions. ${ }^{47}$ During IgE-engaged mast cell activation, Boehmeria possesses inflammatory mediator-suppressive activity and it may be used to treat allergic diseases. After cross-linking the IgE cell surface receptors, mast cells activate a number of mediators, which can cause an allergic response. The fusion of granule membranes in mast cells results in the release of biogenic amines such as histamine, lysosomal enzymes such as beta-hexosaminidase, lipid mediators, and cytokines. ${ }^{48}$ During allergic response, histamine induces vasodilation and capillary leakage, as well as a fever. Histamine degranulation and secretion of $\beta$-hexosaminidase were suppressed by Boehmeria. Antihistamines have related actions but no adverse reactions, so Boehmeria therapy may be established as a choice for allergic disorder therapy. ${ }^{46}$

In macrophages, this is achieved by inhibiting the p38 and JNK MAPK routes, Boehmeria reduces inflammatory cytokine production. ${ }^{49}$ Nevertheless, this research results revealed that p38 and ERK phosphorylation were downregulated by Boehmeria but not by JNK MAPK activation. The p38 and JNK MAPK route are frequently triggered simultaneously, but the extracellular influence and cell type appear to be dependent. ${ }^{50,51}$ Thus, by specifically decreasing the induction of the p38 MAPK route in mast cells, Boehmeria may suppress the development of inflammatory cytokines. By inhibiting H3S10ph induction, similar with p38 MAPK blocker, Boehmeria may contribute to various allergic disorders. ${ }^{50,52}$ Potential of Boehmeria therapy for suppression of proinflammatory cytokine production and in allergic disorders caused by mast cells, inactivation of the ERK MAPK route leads to the production of other lipid intermediaries. Boehmeria decreased the activation of NF- $\mathrm{KB}$ and the development of IL-6 and histamine. Therefore Boehmeria therapy may decrease the NF- $\kappa B$ route, and as a result, decrease IL- 6 expression to decrease histamine synthesis. ${ }^{46}$

\section{Anti-inflammatory activity of Boehmeria}

The proinflammatory activity of Boehmeria may be due to the vesicular properties of the alkylating substances which was used as a cancer treatment, cryptopleurine, close to that of nitrogen mustard. ${ }^{53}$ Some others known phenanthroquinolizidine alkaloids showed chemical correlations with cryptopleurine, so this vesicant properties could be presented and edema induced by all these alkaloids together in high dose. ${ }^{25}$ Some alkaloids which was given in cancer treatment may have vesicant characteristics, such as vinca and taxanes, which, when it interacts with healthy skin, can cause serious vesicle inflammation, edema and tissue destruction. ${ }^{54}$

Combination of inhibitory lipoxygenases (LOX) potential and or cyclooxygenases (COX) or activity as same as a steroidal antiinflammatory medicine would include the anti-inflammatory mode of action of Boehmeria. Blocking the COX and or LOX pathways may also be a feasible way to prevent tumor progression. ${ }^{55}$

Boehmeria, on the other hand, had significantly inhibited the development of inflammatory indicator like IL-6, TNF- $\alpha$ and NO induced by LPS. Furthermore, Boehmeria was also reported to have anti-inflammatory effects of JNK and p38 inhibition. IL-6, TNF- $\alpha$, and $\mathrm{NO}$ are also known pro-inflammatory cytokines formed from LPS (a part of the cell wall of bacteria) to cause inflammatory disease etiology. Fifty-eight Boehmeria had anti-inflammatory capabilities, at least partly due to decreasing in IL-6, NO, iNOS, and TNF- $\alpha$. The activity of Boehmeria on the development of different inflammation-related cytokines has not been documented, however. ${ }^{46,49,56}$

\section{Antidiabetic activity of Boehmeria}

Boehmeria demonstrated that PPAR- $\gamma$ induction, instead of AMPstimulation protein kinase (AMPK) and protein kinase B (Akt) signaling, was associated with the antidiabetic activity. Boehmeriastimulated glucose uptake was correlated with PPAR- $\gamma$ activation and expression but not with AMPK and Akt activation. PPAR- $\gamma$ is involved in glucose uptake, and agonist of PPAR- $\gamma$ improved insulin receptor sensitivity. ${ }^{17,57}$ Natural products or substances have been used as PPAR- $\gamma$ agonists to greatly increase insulin tolerance in addition to thiazolidinedione, a clinically used PPAR- $\gamma$ agonist. ${ }^{58,59}$ The antidiabetic effect of Boehmeria could be explained by activation and expression of PPAR- $\gamma \cdot{ }^{17}$

Insulin-dependent PI3K/Akt signaling and AMPK signaling were not affected by Boehmeria therapy. It means that Boehmeria induced glucose release via PPAR- $\gamma$, implying that Boehmeria may not replicate the effect of insulin or metformin on AMPK stimulation through the insulin receptor. However, the mechanism by which Boehmeria functions as a PPAR- $\gamma$ agonist was unknown. It was possible that PPAR- $\gamma$ agonists raised Glut-4 expression and mRNA levels, thereby stimulated glucose uptake. Furthermore, increasing in PPAR- $\gamma$ transcript levels were associated with increasing in Glut- 4 transcription and glucose intake which indicated that glucose uptake and Glut4 transcription were stimulated by PPAR- $\gamma$ agonists and triggered PPAR- $\gamma$. As a result, Boehmeria's antidiabetic activity may be due to enhancement of PPAR- $\gamma$ and Glut- 4 transcription. Nevertheless, deeper research is needed to understand the cascades that occur downstream of the activation of PPAR- $\gamma$ by Boehmeria extract, which induce glucose intake. ${ }^{17}$ 


\section{Antihyperlipidemic activity of Boehmeria}

Cholinesterase plays a substantial function in lipid metabolism. Plasma cholinesterase value elevation is followed from elevated plasma cholesterol value. ${ }^{22}$ Escalating in cholesterol excretion or reducing in lipid production in the liver may be caused by Boehmeria's cholesterollowering activity. Boehmeria's cholesterol-lowering activity can also be attributed to lower cholinesterase plasma value. Moreover, in the Boehmeria-treated population, the amount of total cholesterol in the blood and the amount of fat in the liver also decreased. Obesity and cardiovascular problems are related with larger average cholesterol level. ${ }^{60}$

In the other hand, in 3T3-L1 cells and pig preadipocytes, Boehmeria reduced lipid aggregation. The aggregation of lipids in 3T3-L1 cells and pig preadipocytes can be impaired by Boehmeria-mediated reduction of proliferation and differentiation. Evaluation of underlying mechanism, further research is required. ${ }^{61}$ Lipoprotein lipase (LPL) is required for lipoprotein metabolism the hydrolysis of triacylglycerol into free fatty acids, and the formation of plasma lipoprotein monoglycerides. ${ }^{62} \mathrm{LPL}$ is a gatekeeper enzyme that regulates the amount of free lipid that enters cells. LPL gene levels and enzyme activity were higher in separated 3T3-
L1 cells. ${ }^{63}$ The current study discovered that treatment with Boehmeria could reduce LPL expression in 3T3-L1 cells and pig preadipocytes. The induction of LPL function after treatment with Boehmeria extract was caused, at least in part, by reducing in the separation between the two cells. ${ }^{61}$

\section{Anti-hepatitis activity of Boehmeria}

Boehmeria greatly decreased $\mathrm{HBs} A g$ and $\mathrm{HBeAg}$ released into the environment and blocked HBV DNA synthesis in HepG2.2.15 cells without inducing cytotoxicity. On the other hand, the Boehmeria extract's part was critical for unidentified anti-HBV activity. The previous research stated a hypothesize that organic acids and terpenoids could be the functional ingredients in phenolic compounds that give them anti-HBV properties. ${ }^{23}$

Several studies on the phytochemical compounds and pharmacological activities of Boehmeria genus have also been performed (Table 1).

\section{CONCLUSION}

This study showed that plants in Boehmeria genus are very important because they contained large number of compounds with a wide range

Table 1: Phytochemical compounds and pharmacological activities of Boehmeria genus.

\begin{tabular}{|c|c|c|c|c|}
\hline Species & Phytochemical & Pharmacology & Mechanism & Reference \\
\hline B. virgate & $\begin{array}{l}\text { Phenanthrene alkaloid as 10-(6,6-dihydroxy-hexyl)-2,3,6- } \\
\text { trimethoxy-phenanthrene-9-carboxylic acid amide }\end{array}$ & Anticancer & $\begin{array}{l}\text { Induction apoptosis by caspase- } 3 \\
\text { activity. }\end{array}$ & $8,9,10$ \\
\hline B. siamensis & Boehmeriasin A and boehmeriasin B & Anticancer & $\begin{array}{l}\text { Induces cell cycle arrest in the G1 phase, } \\
\text { expression of cyclin E2 and cyclin D1, } \\
\text { topoisomerase inhibition. }\end{array}$ & $12,13,64$ \\
\hline B. nivea & $\begin{array}{l}\text { Chlorogenic acid, epicatechin, unsaturated fatty acids as (E } \\
\text { )-8,11,12-trihydroxy-9-octadecenoic acid and (Z)-9,10,11- } \\
\text { trihydroxy-12 octadecenoic acid, (Z)-12-keto-7,8,9-trihydroxy- } \\
\text { 10-hexadecenoic acid, (Z)-7,8,9-trihydroxy-10-bexadecenoic } \\
\text { acid, quinolizidine alkaloid as 3-(4-hydroxyphenyl)-4-(3- } \\
\text { methoxy-4-hydroxyphenyl)-3,4-dehydroquinolizidine, rutin, } \\
\text { naringin, hesperidin, caffeic acid, catechin, epicatechin, } \\
\text { luteolin-7-glucoside, } \beta \text {-sissterol, tangeretin, acetophenone. } \\
\text { phenanthroquinolizidine alkaloids as cryptopleurine, } \\
\text { boehmeriasin A, boehmeriasin B, julandine, and (-)-C(15R)- } \\
\text { hydroxycryptopleurine }\end{array}$ & $\begin{array}{l}\text { Antiproliferative, } \\
\text { antioxidant, anticancer, } \\
\text { anti-inflammatory, anti- } \\
\text { obesity, antibacterial, } \\
\text { and hypoglycemic and } \\
\text { hypolipidemic effects, } \\
\text { anti-colitis, anti-hepatitis } \\
\text { B, laxative. }\end{array}$ & $\begin{array}{l}\text { a-glucosidase inhibitory, inhibiting } \\
\text { p38, JNK phosphorylation, } \\
\text { inhibitors of histamine and } \\
\beta \text {-hexosaminidase release, suppressing } \\
\text { pro-inflammatory cytokines (TNF- } \alpha \text {, } \\
\text { IL-1 } \beta \text {, and IL-6), inhibition of LOX } \\
\text { and/or COX, reduced the production } \\
\text { of IL-6 and MCP-1, suppresses } \\
\text { adipogenic, inhibit lipoprotein } \\
\text { lipase activity and triglyceride } \\
\text { accumulation. }\end{array}$ & $16-24,46$ \\
\hline B. caudata & $\begin{array}{l}\text { Boehmeriasin A, boehmeriasin B, julandine, (-)-C(15R)- } \\
\text { hydroxycryptopleurine, 3-(4-Hydroxyphenyl)-4-(3-methoxy-4- } \\
\text { hydroxyphenyl)-3, 4-dehydroquinolizidine, 3,4-Dimethoxy- } \omega \text { - } \\
\text { (2'-piperidy1) acetophenone, and 2',4'Dimethoxyacetofenone, } \\
\text { chlorogenic acid as 3-Caffeoylquinic acid, 5-Caffeoylquinic } \\
\text { acid, 3,4-Dicaffeoylquinic acid, 3,5-Dicaffeoylquinic acid, and } \\
\text { 4,5-Dicaffeoylquinic acid }\end{array}$ & $\begin{array}{l}\text { Anticancer, anti- } \\
\text { inflammatory }\end{array}$ & $\begin{array}{l}\text { Antiproliferative and anti- } \\
\text { inflammatory properties are related, } \\
\text { blocking lipoxygenases (LOX) and } \\
\text { cyclooxygenases (COX) pathways. }\end{array}$ & $25,26,55$ \\
\hline B. macrophylla & $\begin{array}{l}\text { Tannin, flavonoids, saponin, steroid, alkaloid, terpenoid, } \\
\text { emodin, } \beta \text {-sitosterol, } \beta \text {-sitosterol glucoside, ursolic acid, } \\
\text { 7-hydroxy- } 6 \text {-methoxycoumarin, sweroside, cinnamic acid, and } \\
\text { genistein }\end{array}$ & $\begin{array}{l}\text { Analgesic, antioxidant, } \\
\text { antibacterial }\end{array}$ & $\begin{array}{l}\text { Increasing the amount of endogenous } \\
\text { serotonin or interacting with the } \\
5 \text {-HT2A and 5-HT3 receptors }\end{array}$ & $15,27,28$ \\
\hline B. tricuspis & Rutin, isoquercetin, Kaempferol-3-O-rutinoside & Antioxidant & No reported & 14,15 \\
\hline B. gracilis & Rutin, isoquercetin, Kaempferol-3-O-rutinoside & No reported & No reported & 14 \\
\hline B. pannosa & $\begin{array}{l}\text { Rutin, isoquercetin, Kaempferol-3-O-rutinoside, } \\
\text { Cryptopleurine }\end{array}$ & No reported & No reported & 14 \\
\hline B. platanifolia & Rutin, isoquercetin, Kaempferol-3-O-rutinoside & No reported & No reported & 14 \\
\hline B. quelpaertensis & $\begin{array}{l}\text { Rutin, isoquercetin, Kaempferol-3-O-rutinoside, } \\
\text { Cryptopleurine }\end{array}$ & No reported & No reported & 14 \\
\hline B. spicata & Rutin, isoquercetin, Kaempferol-3-O-rutinoside & No reported & No reported & 14 \\
\hline B. splitgerbera & $\begin{array}{l}\text { Rutin, isoquercetin, Kaempferol-3-O-rutinoside, } \\
\text { Cryptopleurine }\end{array}$ & No reported & No reported & 14 \\
\hline $\begin{array}{l}\text { B. japovanica var. } \\
\text { longispica }\end{array}$ & $\begin{array}{l}\text { Rutin, isoquercetin, Kaempferol-3-O-rutinoside, } \\
\text { Cryptopleurine }\end{array}$ & Antioxidant & No reported & 14,15 \\
\hline B. nivea var. concolor & Rutin, isoquercetin, & No reported & No reported & 14 \\
\hline B. clidemioides & Phenolic, flavonoid & Antioxidant & No reported & 15 \\
\hline B. penduliflora & Phenolic, flavonoid & Antioxidant & No reported & 15 \\
\hline
\end{tabular}


of medicinal activities that can be used to produce medicine from natural materials. Some of the confirmed pharmacological studies are as follows as antiproliferative, antioxidant, anticancer, anti-inflammatory, anti-obesity, antibacterial, hypoglycemic and hypolipidemic effects, anti-colitis, anti-hepatitis B, and laxative.

Several literatures have reported phytochemical compounds that have been isolated from Boehmeria genus, such as 10-(6,6-dihydroxyhexyl)-2,3,6-trimethoxy-phenanthrene-9-carboxylic acid amide, boehmeriasin A, boehmeriasin B, chlorogenic acid, epicatechin, (Z)9,10,11-trihydroxy-12 octadecenoic acid, catechin, $\beta$-sitosterol, rutin, luteolin-7-glucoside, naringin and hesperidin.

Boehmeria genus has potential to be developed in dosage form both conventional and modern medicine.

\section{ACKNOWLEDGEMENT}

The authors would like to acknowledge the Department of Pharmaceutical Biology, School of Pharmacy, Bandung Institute of Technology, Indonesia, for their support in terms of facilities.

\section{REFERENCES}

1. Pevsić M. Development of natural product drugs in a sustainable manner. In 2015.

2. Bauer A, Brönstrup M. Industrial natural product chemistry for drug discovery and development. Nat. Prod. Rep 2014; 31(1): 35-60.

3. Kushiro T, Nambara E, McCourt P. Hormone evolution: The key to signalling. Nature 2003; 422(6928): 122-122.

4. Wink M. Interference of alkaloids with neuroreceptors and ion channels. Stud. Nat. Prod. Chem 2000; 21: 3-122.

5. Powo. Plants of the World Online [Internet]. Facilitated by the Royal Botanic Gardens, Kew. 2009 [cited 2021 Feb 12]. Available from: http://powo.science.kew.org/?f=accepted_names\&q=boehmeria.

6. Wilmot-Dear CM, Friis I, Thomas Z. New species in old world Boehmeria (Urticaceae). Edinburgh J .Bot 2010; 67(3): 431-450.

7. Liang YK, Liu WC, Chen JH, Chen XR, Tang Q, Sun ZM, et al. Relationships among Chinese Boehmeria species and the evolution of various clade. Ind. Crops Prod 2020; 148(January): 112092. https://doi.org/10.1016/j.indcrop.2020.112092.

8. Lukman M, Wahyudin E, Manggau MA. Research article cytotoxic effect of four Makassarese medicinal plants on human cervical cell lines and its selectivity. J. Chem. Pharm. Res 2014; 6(10): 851-855.

9. Manggau MA, Andriani F, Murdifin M, Nurdin WB, Yulianti R, Usmar, et al. In vitro study of the alkaloid anticancer compound from Makassar medicinal plants Boehmeria virgata Linn. Int. J. Pharm. Sci. Rev. Res 2018; 49(1)(13): 77-81.

10. Manggau M, Lukman. Effect of an isolated active compound (BVI03) of Boehmeria virgata (Forst) Guill leaves on anti-proliferation in human cancer cervix HeLa cells through activation of caspase 3 and p53 protein. Trop. Med. Surg 2013; 1(3): 3-6.

11. Yan J, Luo D, Luo Y, Gao X, Zhang G. Induction of G1 arrest and differentiation in MDA-MB-231 breast cancer cell by boehmeriasin A, a novel compound from plant. Int. J. Gynecol. Cancer 2006; 16(1):165-170.

12. Christodoulou MS, Calogero F, Baumann M, García-Argáez AN Pieraccini S, Sironi M, et al. Boehmeriasin A as new lead compound for the inhibition of topoisomerases and SIRT2. Eur. J. Med. Chem 2015; 92: 766-775

13. Güzelcan EA, Baxendale IR, Cetin-Atalay R, Baumann M. Synthesis of new derivatives of boehmeriasin $A$ and their biological evaluation in liver cancer. Eur. J. Med. Chem 2019; 166: 243-255. https://doi. org/10.1016/j.ejmech.2019.01.056.
14. Akter KM, Kim HJ, Khalil AAK, Park WS, Lee MK, Park JH, et al. Inner morphological and chemical differentiation of Boehmeria species. J. Nat. Med 2018; 72(2): 409-423. https://doi.org/10.1007/ s11418-017-1164-8

15. Chen $Y$, Wang G, Wang $H$, Cheng $C$, Zang G, Guo X, et al. Phytochemical profiles and antioxidant activities in six species of ramie leaves. PLoS One. 2014; 9(9): e108140.

16. Yang Z, Tan Z, Li F, Li X. An effective method for the extraction and purification of chlorogenic acid from ramie (Boehmeria nivea L.) leaves using acidic ionic liquids. Ind. Crops Prod 2016; 89:78-86. http://dx.doi.org/10.1016/j.indcrop.2016.05.006

17. Kim SH, Sung MJ, Park JH, Yang HJ, Hwang JT. Boehmeria nivea stimulates glucose uptake by activating peroxisome proliferatoractivated receptor gamma in $\mathrm{C} 2 \mathrm{C} 12$ cells and improves glucose intolerance in mice fed a high-fat diet. Evid Based Complement. Alternat. Med 2013; 2013: 867893

18. Wang H, Qiu C, Chen L, Abbasi AM, Guo X, Liu RH. Comparative study of phenolic profiles, antioxidant and antiproliferative activities in different vegetative parts of ramie (Boehmeria nivea L.). Molecules 2019; 24(8).

19. Xu QM, Liu YL, Li XR, Li X, Yang SL. Three new fatty acids from the roots of Boehmeria nivea (L.) Gaudich and their antifungal activities. Nat. Prod. Res 2011; 25(6): 640-647.

20. Qaromah AA, Wulandari AP, Harneti D. Cytotoxicity of ramie (Boehmeria nivea L. Gaud.) leaves extract on MCF-7 breast cancer cell Line. World J. Pharm. Pharm. Sci 2020; 9(5): 974-987.

21. Nho JW, Hwang IG, Kim HY, Lee YR, Woo KS, Hwang BY, et al Free radical scavenging, angiotensin l-converting enzyme (ACE) inhibitory, and in vitro anticancer activities of ramie (Boehmeria nivea) leaves extracts. Food Sci. Biotechnol 2010; 19(2): 383-390.

22. Sancheti S, Sancheti S, Bafna M, Kim HR, You YH, Seo SY. Evaluation of antidiabetic, antihyperlipidemic and antioxidant effects of Boehmeria nivea root extract in streptozotocin-induced diabetic rats. Rev. Bras. Farmacogn 2011; 21(1): 146-154.

23. Wei J, Lin L, Su X, Qin S, Xu Q, Tang Z, et al. Anti-hepatitis B virus activity of Boehmeria nivea leaf extracts in human HepG2.2.15 cells. Biomed. Reports 2014; 2(1): 147-151.

24. Lee HJ, Choi EJ, Park S, Lee JJ. Laxative and antioxidant effects of ramie (Boehmeria nivea L.) leaf extract in experimental constipated rats. Food Sci. Nutr 2020; 8(7): 3389-3401

25. de Paiva PP, Nonato FR, Ruiz ALTG, Sousa IM de O, Zafred RRT, de Oliveira DN, et al. An ethanolic extract of Boehmeria caudata aerial parts displays anti-inflammatory and anti-tumor activities. Planta Medica Int. Open 2020; 7(01): e17-25.

26. Paiva P, Nonato F, Zafred R, Sousa I, Ruiz A, Foglio M, et al. Antiinflammatory activity of Boehmeria caudata Sw. (Urticaceae) crude ethanol extract on croton oil mouse ear oedema. Planta Med 2014 80(16).

27. Min Y, Yang J, Ping Y, Liu W. Chemical constituents of Boehmeria macrophylla Hornem. Adv. Mater. Res 2012; 550-553: 1378-1380.

28. Hossain A, Islam F, Saifuzzaman M, Saeed MAS, Islam MK, Murshid GMM, et al. Bioactivity of Boehmeria macrophylla (Urticaceae) leaf extract. Orient. Pharm. Exp. Med 2016; 16(3): 233-241. http:// dx.doi.org/10.1007/s13596-016-0230-1

29. Goldar S, Khaniani MS, Derakhshan SM, Baradaran B. Molecular mechanisms of apoptosis and roles in cancer development and treatment. Asian Pacific J. Cancer Prev 2015; 16(6): 2129-2144.

30. Hassan M, Watari H, AbuAlmaaty A, Ohba Y, Sakuragi N. Apoptosis and molecular targeting therapy in cancer. Biomed. Res. Int 2014; 2014: 150845

31. Arbiser JL, Bonner MY, Gilbert LC. Targeting the duality of cancer. NPJ Precis. Oncol 2017; 1(1): 1-7. http://dx.doi.org/10.1038/s41698017-0026-X 
32. Lopes J, Tait SWG. Mitochondrial apoptosis: Killing cancer using the enemy within. Br. J. Cancer 2015; 112(6): 957-962. http:// dx.doi.org/10.1038/bjc.2015.85

33. Zaman S, Wang R, Gandhi V. Targeting the Apoptosis Pathway. Leuk Lymphoma 2014; 55(9): 1980-1992.

34. Mcllwai DR, Berger T, Mak TW. Caspase functions in cell death and disease. Cold Spring Harb. Perspect. Biol 2015; 7(4): a008656.

35. Lu H, Gan M, Zhang G, Zhou T, Yan M, Wang S. Expression of survivin, caspase-3 and p53 in cervical cancer assessed by tissue microarray: correlation with clinicopathology and prognosis. Eur. J. Gynaecol. Oncol 2010; 31(6): 662-666. http://europepmc.org/ abstract/MED/21319512

36. Halaby R. Novel anticancer agent for chemoresistant cancer cells that are caspase-3 deficient. J. Mol. Biol. Mol. Imaging 2014; 1(3): 8.

37. Hong B, Heuvel A, Prabhu V, Zhang S, El-Deiry W. Targeting tumor suppressor p53 for cancer therapy: Strategies, challenges and opportunities. Curr. Drug Targets 2014; 15(1): 80-89.

38. Hientz K, Mohr A, Bhakta-Guha D, Efferth T. The role of p53 in cancer drug resistance and targeted chemotherapy. Oncotarget 2017; 8(5): 8921-8946.

39. He X, Liu RH. Phytochemicals of apple peels: Isolation, structure elucidation, and their antiproliferative and antioxidant activities. J. Agric. Food Chem 2008; 56(21): 9905-9910.

40. Yang J, Liu RH. The phenolic profiles and antioxidant activity in different types of tea. Int. J. Food Sci. Technol 2013; 48(1): 163-171.

41. Lobo V, Patil A, Phatak A, Chandra N. Free radicals, antioxidants and functional foods: Impact on human health. Pharmacogn. Rev 2010; 4(8): 118-126.

42. Akhlagi M, Bandy B. Mechanisms of flavonoid protection against myocardial ischemia-reperfusion injury. J. Mol. Cell. Cardiol 2009; 46(3): 309-317. http://dx.doi.org/10.1016/j.yjmcc.2008.12.003

43. Jung $\mathrm{CH}$, Lee JY, Cho $\mathrm{CH}$, Kim CJ. Anti-asthmatic action of quercetin and rutin in conscious guinea-pigs challenged with aerosolized ovalbumin. Arch. Pharm. Res 2007; 30(12): 1599-1607.

44. Choi JK, Kim S. Rutin suppresses atopic dermatitis and allergic contact dermatitis. Exp. Biol. Med 2013; 238: 410-417.

45. Kilic K, Sedat M, Serkan S, Fatih Y, Kandemir M, Sitki M. The amendatory effect of hesperidin and thymol in allergic rhinitis: an ovalbumin-induced rat model. Eur. Arch. Oto-Rhino-Laryngology 2019; 276(2): 407-415. http://dx.doi.org/10.1007/s00405-018-5222-y

46. Lim J-Y, Lee J-H, Lee B-R, Kim MA, Lee Y-M, Kim D-K, et al. Extract of Boehmeria nivea suppresses mast cell-mediated allergic inflammation by inhibiting mitogen-activated protein kinase and nuclear factor-kB. Molecules 2020; 25(18): 4178.

47. Amin K. The role of mast cells in allergic inflammation. Respir. Med 2012; 106(1): 9-14. https://www.sciencedirect.com/science/article/ pii/S0954611111003325

48. A. Abbas, A. Litchman, S. Pillai, D. Baker AB. Cellular and molecular immunology. 9th ed. Philadelphia, PA: Elsivier; 2018.
49. Sung MJ, Davaatseren M, Kim SH, Kim MJ, Hwang JT. Boehmeria nivea attenuates LPS-induced inflammatory markers by inhibiting p38 and JNK phosphorylations in RAW264.7 macrophages. Pharm. Biol 2013; 51(9): 1131-1136.

50. Azzolina A, Guarneri P, Lampiasi N. Involvement of p38 and JNK MAPKs pathways in substance P-induced production of TNF- by peritoneal mast cells. Cytokine 2002; 18(2): 72-80.

51. Lin A, Minden A, Martinetto H, Claret F, Lange-carter C, Mercurio F, et al. Identification of a dual specificity kinase that activates the Jun kinases and p38-Mpk2. Science 1995; 268(5208): 286-290.

52. Marwick JA, Tudor C, Khorasani N, Michaeloudes C. Oxidants induce a corticosteroid-insensitive phosphorylation of histone 3 at serine 10 in monocytes. PLoS One 2015; 1-12.

53. Fridrichsons J, Mathieson AM. Structure of a derivative of cryptopleurine. Nature 1954; 173(4407): 732-723. https://doi. org/10.1038/173732a0

54. Kreidieh FY, Moukadem HA, El Saghir NS. Overview, prevention and management of chemotherapy extravasation. World J. Clin. Oncol 2016; 7(1): 87-97

55. Paiva PP de, Nunes JHB, Nonato FR, Ruiz ALTG, Zafred RRT, Sousa IMO, et al. In silico, in vitro, and in vivo antitumor and antiinflammatory evaluation of a standardized alkaloid-enriched fraction obtained from Boehmeria caudata Sw. aerial parts. Molecules 2020; 25(17). https://www.mdpi.com/1420-3049/25/17/4018

56. Shea JJO, Ma A, Lipsky P. Cytokines and autoimmunity. Nat. Rev. Immunol 2002; 2(1): 37-45.

57. Liu Q, Chen L, Hu L, Guo Y, Shen X. Biochimica et biophysica acta small molecules from natural sources, targeting signaling pathways in diabetes. BBA - Gene Regul. Mech 2010; 1799(10-12): 854-865. http://dx.doi.org/10.1016/j.bbagrm.2010.06.004

58. Eng TD, Han SS, Zhi-bin LI, Zhong-wen WU, lao CL, Ben KO, et al. A new retinoid-like compound that activates peroxisome proliferatoractivated receptors and lowers blood glucose in diabetic mice. Biol. Pharm. Bull. 2005; 8(7): 1192-1196.

59. Petersen RK, Christensen KB, Assimopoulou AN, Kouskoumvekak I. Pharmacophore-driven identification of PPAR $\mathrm{c}$ agonists from natural sources. J. Comput. Aided Mol. Des 2011; 25:107-116.

60. Sancheti S, Sancheti S, Seo S-Y. Evaluation of antiglycosidase and anticholinesterase activities of Boehmeria nivea. Pak. J. Pharm. Sci 2010; 23(2): 236-240.

61. Lee J, Kim AR, Lee JJ. Ramie leaf extracts suppresses adipogenic differentiation in 3T3-L1 cells and pig preadipocytes. AsianAustralasian J. Anim. Sci 2016; 29(9): 1338-1344.

62. Wang $\mathrm{H}$, Eckel $\mathrm{RH}$. Lipoprotein lipase: from gene to obesity. Am. J. Physiol. Endocrinol. Metab 2009; 297(2): E271-88.

63. Semenkovich CF, Wims M, Noe L, Etienne J, Chan L. Insulin regulation of lipoprotein lipase activity in 3T3-L1 adipocytes is mediated at posttranscriptional and posttranslational levels. J. Biol. Chem 1989; 264(15): 9030-9308. 


\section{GRAPHICAL ABSTRACT}

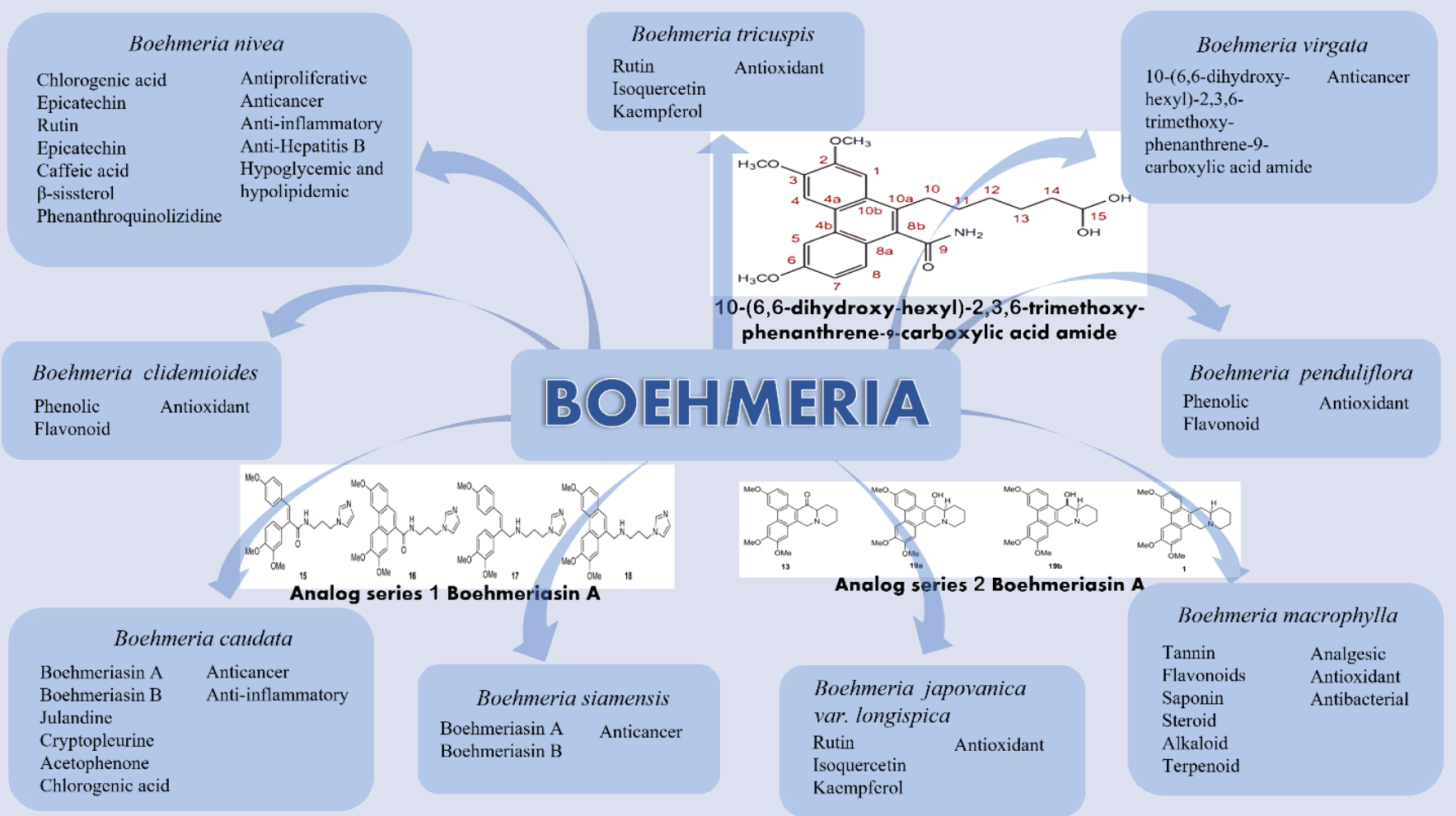

\section{ABOUT AUTHORS}
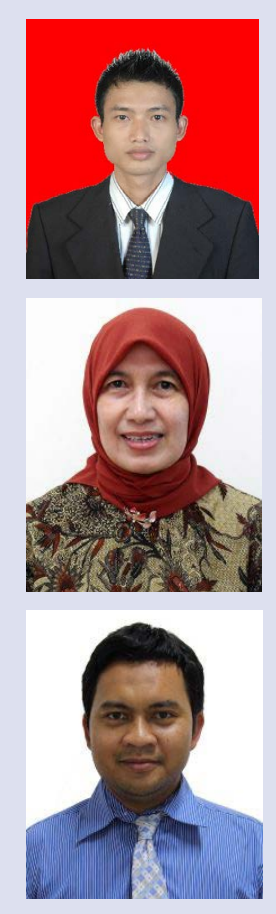

Muhammad Ikhlas Arsul is a Doctoral student in School Pharmacy, Bandung Institute of Technology, and a lecture in Department of Pharmacy, Alauddin Islamic State University, Indonesia. Develop work in pharmacognosy of natural material.

Dr. Irda Fidrianny is a Professor of Phytochemistry at School Pharmacy, Bandung Institute of Technology. Develop work in phytochemical and standardization of natural materials.

Dr. Muhamad Insanu is an Associate Professor at the Department of Pharmaceutical Biology, School of Pharmacy, Bandung Institute of Technology. Develop work in pharmacognosy and phytochemical of natural materials.

Cite this article: Arsul MI, Insanu M, Fidrianny I. Phytochemistry and Pharmacological Activities of Boehmeria Genus: An Update Review. Pharmacogn J. 2021;13(6): 1533-1541. 